\title{
Structural Chemistry of Anhydrous Sodium Silicates - A Review
}

\author{
Volker Kahlenberg*
}

\begin{abstract}
Sodium silicates are of considerable importance for many fields of inorganic chemistry and applied mineralogy, being either raw materials for synthesis or already finished products. In addition to their industrial relevance they have also been studied intensively because of their interesting physico-chemical properties including high ion-exchange capacity and selectivity or two-dimensional sodium diffusion and conductivity. Furthermore, the structural chemistry of crystalline sodium silicates offers the crystallographer challenging tasks such as polytypism, polymorphism, temperature and/or pressure-dependent phase transitions, pseudo-symmetry, complex twinning phenomena as well as incommensurately modulated structures. Many of these structural problems have been solved only recently, although in some cases they have been known for several decades. This article will provide an overview on the structurally characterized sodium silicates and their fascinating crystallochemical characteristics.
\end{abstract}

Keywords: Crystal chemistry $\cdot$ Polymorphism $\cdot$ Sodium silicates

\section{Introduction}

Since the early investigations of Morey[1] and Morey and Bowen ${ }^{[2]}$ the system $\mathrm{Na}_{2} \mathrm{O}-$ $\mathrm{SiO}_{2}$ has been the subject of many studies focussing on the elucidation of the phase relationships between the crystalline compounds. ${ }^{[3-12]}$ Two slightly modified recent phase diagrams covering the whole compositional space are given in Fig. 1. This interest is mainly due to the fact that anhydrous sodium silicates are of considerable importance as raw materials or already finished products in both inorganic chemistry and technical mineralogy. Fields of industrial applications include production of water glass solutions or manufacture of acid-resistant enamel frits. Furthermore, they are used as components in refractory cements, as inorganic binders, or builders in washing powders (in combination with or as an alternative to zeolites) ${ }^{[13]}$ - to mention but a few. In the field of fundamental research crystalline sodium silicates such as $\mathrm{Na}_{2} \mathrm{Si}_{2} \mathrm{O}_{5}$ have been studied for their high ion-exchange capacity and selectiv-

${ }^{*}$ Correspondence: Dr. V. Kahlenberg Institute of Mineralogy and Petrography University of Innsbruck

Innrain 52, A-6020 Innsbruck, Austria Tel.: ++43 5125075503

E-Mail: volker.kahlenberg@uibk.ac.at ity $^{[14]}$ or their two-dimensional sodium diffusion and conductivity properties.[15] On the other hand, the binary system sodium oxide-silicon dioxide simultaneously contains a classical network former $\left(\mathrm{SiO}_{2}\right)$ and a network modifier $\left(\mathrm{Na}_{2} \mathrm{O}\right)$ and, therefore, has been frequently used as a simple model system to understand the much more complex processes in igneous or technical silicate melts and glasses. ${ }^{[16-20]}$

However, sodium silicates are also of interest from a crystallochemical point of view. In contrast to their comparatively simple chemistry as oxides of main group elements, challenging crystallographic problems including polytypism, polymorphism, pseudo-symmetry, temperature and/or pressure-dependent phase transitions, complex twinning phenomena and incommensurately modulated structures have been observed. For example, sodium disilicate can crystallize in at least seven different modifications, which represents one of the highest numbers of polymorphs that have been reported for an inorganic material. In this context it is important to note that the crystal structures of several sodium silicates have been determined only recently although in some cases their existence has been known for more than eighty years. Apart from the crystallographic difficulties mentioned above this can be at least partially attributed to the fact that especially in the $\mathrm{SiO}_{2}$-rich region i) equilibrium conditions are notoriously difficult to obtain and ii) metastable compounds exist whose preparation requires specific temperature-time treatments. On the other hand, the very $\mathrm{Na}_{2} \mathrm{O}$-rich compounds are not easy to handle experimen- tally and have to be protected against air and moisture. The corresponding melts in turn are corrosive to many crucible materials and subject to $\mathrm{Na}_{2} \mathrm{O}$-losses.

The basic idea of the present contribution was to provide a summary of the results that have been obtained in the course of structural investigations on sodium silicates. In the first part emphasis will be on materials based on $\left[\mathrm{SiO}_{4}\right]$-tetrahedra (socalled tetraoxosilicates). The second part will focus on high pressure Na-silicates where silicon has been found to adopt fourand six-fold oxygen coordinations simultaneously (so called mixed tetra-hexaoxosilicates). Finally, several structurally noncharacterized phases will be addressed.

\section{Tetraoxosilicates}

\section{$\mathrm{Na}_{4} \mathrm{SiO}_{4}$}

$\mathrm{Na}_{4} \mathrm{SiO}_{4}$ is the $\mathrm{Na}_{2} \mathrm{O}$-richest compound of the binary system on which structural investigations have been performed. A congruent melting behaviour was established unequivocally, although the reported melting points differ significantly $(1351 \mathrm{~K}$ in ref. [4] and $1383 \mathrm{~K}$ in ref. [10], respectively). From a structural point of view, triclinic $\mathrm{Na}_{4} \mathrm{SiO}_{4}$ belongs to the group of nesosilicates, i.e. it is based on isolated $\left[\mathrm{SiO}_{4}\right]$-groups. ${ }^{[21,22]}$ The sodium atoms are coordinated by four to five nearest oxygen neighbours. The $\left[\mathrm{NaO}_{4}\right]$-tetrahedra share common edges and form one-dimensional chains running parallel to [010]. By sharing common corners, these chains are linked to the $\left[\mathrm{SiO}_{4}\right]$-tetrahedra building a layer parallel to (001). The remaining 


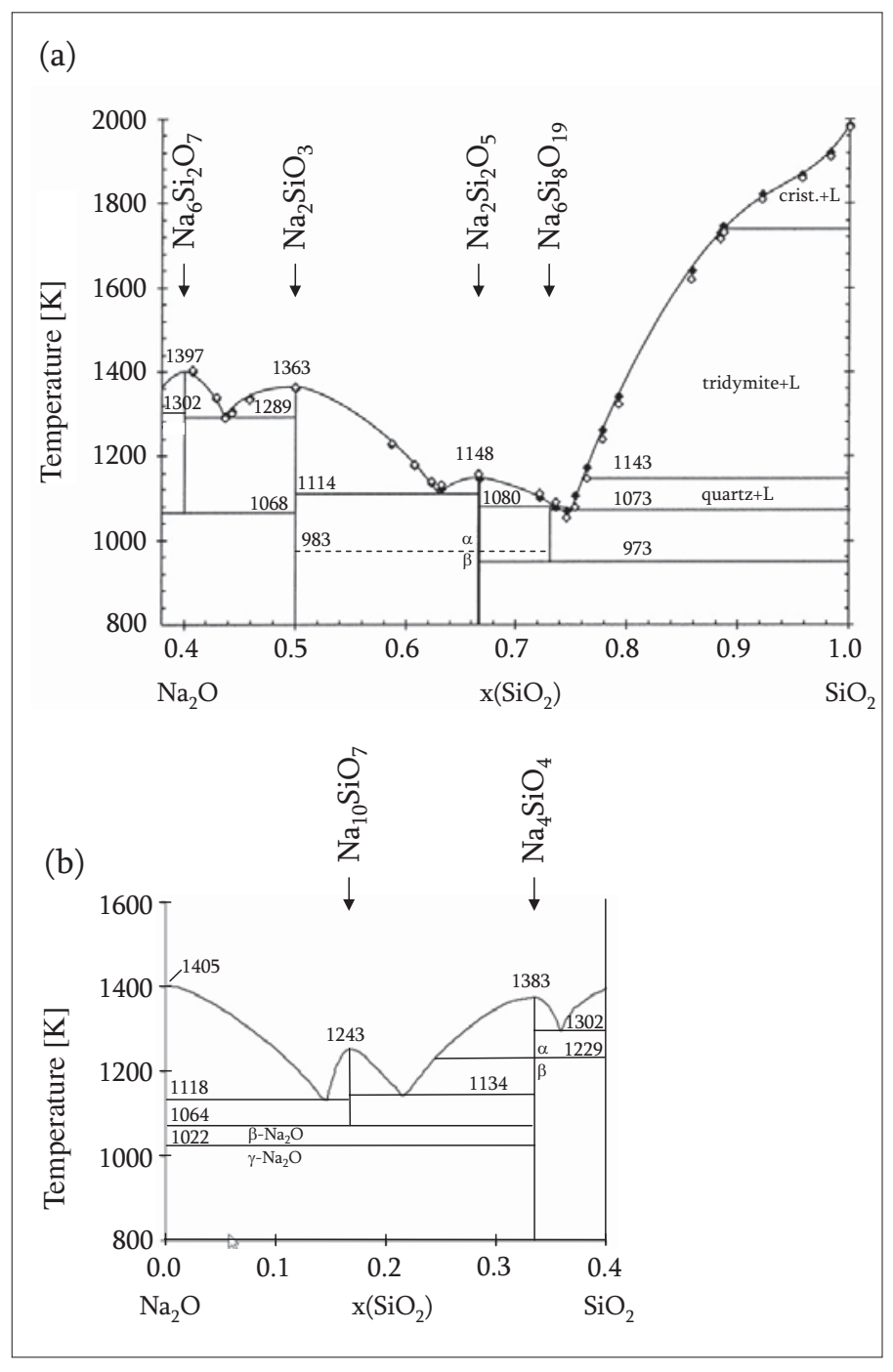

fivefold-coordinated sodium atoms are incorporated within the structure to provide charge neutrality (Fig. 2). According to thermal investigations performed by D'Ans and Löffler ${ }^{[4]}$ as well as Löffler ${ }^{[23]}$ it can be concluded that $\mathrm{Na}_{4} \mathrm{SiO}_{4}$ undergoes a reversible structural phase transition at about $1233 \mathrm{~K}$. However, so far the crystal structure of the high temperature modification $\left(\alpha-\mathrm{Na}_{4} \mathrm{SiO}_{4}\right)$ has not been determined.

\section{$\mathrm{Na}_{6} \mathrm{Si}_{2} \mathrm{O}_{7}$}

In 1930, D'Ans and Löffler ${ }^{[4]}$ were the first to mention the existence of a congruently melting sodium pyrosilicate with composition $3 \mathrm{Na}_{2} \mathrm{O} \cdot 2 \mathrm{SiO}_{2}$ (melting point: $1388 \mathrm{~K})$. First basic structural data including a powder diffraction pattern as well as a proposal for the unit cell parameters for $\mathrm{Na}_{6} \mathrm{Si}_{2} \mathrm{O}_{7}$ were given by Kautz, Müller and Schneider. ${ }^{[24]}$ Moreover, the same authors reported that this phase has a lower stability limit of about $893 \mathrm{~K}$ but that it can be preserved at ambient conditions by quenching from higher temperatures. According to Zaitsev et al. ${ }^{[8]} \mathrm{Na}_{6} \mathrm{Si}_{2} \mathrm{O}_{7}$ becomes unstable below $1068 \mathrm{~K}$ where it disproportionates into $\mathrm{Na}_{4} \mathrm{SiO}_{4}$ and $\mathrm{Na}_{2} \mathrm{SiO}_{3}$. The significant
Fig. 1. Slightly modified phase diagrams for the system $\mathrm{Na}_{2} \mathrm{O}-\mathrm{SiO}_{2}$ (a) based on the data given in refs $[8,12]$ for $\mathrm{SiO}_{2}$ contents between about 0.4 and 1.0 mole fractions as well as (b) for the region between 0.0 and 0.4 $x\left(\mathrm{SiO}_{2}\right) \cdot{ }^{[10,11]}$

differences between the two temperatures can be attributed to the techniques that were used for the studies (X-ray powder diffraction as well as effusion cell measurements, respectively). The higher value corresponds to the 'real' thermodynamic stability, whereas the lower value reflects the kinetic stability. Only recently single crystals of $\mathrm{Na}_{6} \mathrm{Si}_{2} \mathrm{O}_{7}$ were grown in our laboratory. We were able to show that the large pseudo-tetragonal monoclinic C-centred unit cell proposed by Kautz et $a l$. is incorrect and can be explained due to twinning by reticular merohedry of two much smaller triclinic cells. Structure determination using a data set from a twinned crystal was possible. ${ }^{[25]}$ According to the structure analysis $\mathrm{Na}_{6} \mathrm{Si}_{2} \mathrm{O}_{7}$ can be classified as a sorosilicate. The $\mathrm{Si}_{2} \mathrm{O}_{7}$-dimers are arranged in layers parallel to (100). Charge compensation within the structure is accomplished by sodium cations, which are distributed among a total of 24 crystallographically independent positions. The sodium positions are coordinated by four to six nearest oxygen neighbors. Most of the coordination polyhedra can be approximately described as distorted tetrahedra or

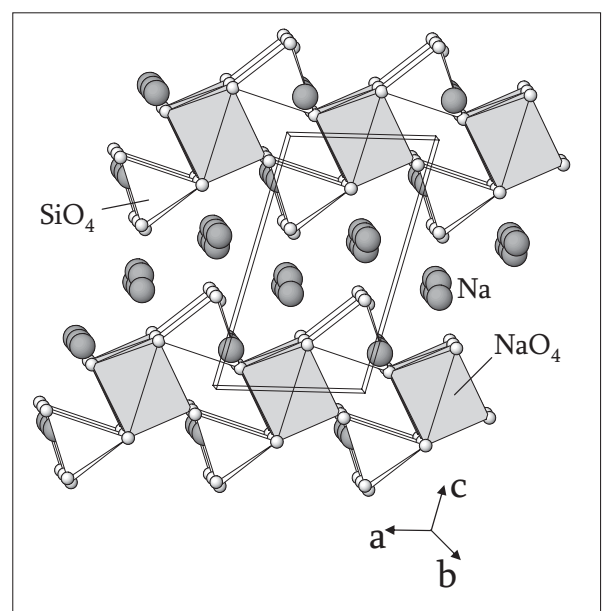

Fig. 2. Side view of the crystal structure of $\mathrm{Na}_{4} \mathrm{SiO}_{4}$. $\left[\mathrm{SiO}_{4}\right]$ - and $\left[\mathrm{NaO}_{4}\right]$-tetrahedra are shown in white and grey, respectively. $\mathrm{Na}$ atoms with higher coordination numbers are given as spheres.

tetragonal pyramids. The $\mathrm{NaO}_{\mathrm{n}}$-polyhedra are joined by corner- or edge-sharing.

A slightly different understanding of the structure can be obtained when the group of tetrahedrally coordinated sodium atoms is considered for the construction of a tetrahedral framework. Within the structure, each four of the $\mathrm{Si}_{2} \mathrm{O}_{7}$-units are linked by a more or less distorted $\left[\mathrm{NaO}_{4}\right]$-group. The resulting structural motive is similar to the one which can be observed in melilites where linkage between the $\mathrm{T}_{2} \mathrm{O}_{7}$ ( $\mathrm{T}: \mathrm{Al}$, $\mathrm{Si}$ ) moieties is provided by $\left[\mathrm{MgO}_{4}\right]$ - (as in akermanite) or $\left[\mathrm{AlO}_{4}\right]$-tetrahedra (as in gehlinite). By sharing of common edges, the $\left[\mathrm{NaO}_{4}\right]$-groups in sodium pyrosilicate are forming one-dimensional rows running parallel to [100]. The resulting network contains tunnels where the remaining $\mathrm{Na}$ cations with higher coordination numbers are located (Fig. 3).

\section{$\mathrm{Na}_{2} \mathrm{SiO}_{3}$}

The crystal structure of sodium metasilicate is known for almost sixty years. ${ }^{[26]}$ Later re-investigations ${ }^{[27]}$ confirmed the principal correctness of the previous structural model, however, the quality of the refinement could be considerably improved. Actually, $\mathrm{Na}_{2} \mathrm{SiO}_{3}$ is an ino- or chain silicate. The structure is based on zweier single chains running parallel to [001] of the orthorhombic unit cell (Fig. 4). Linkage between the chains is provided by sodium atoms which are surrounded by five oxygen anions in form of distorted trigonal bipyramids. Richet et al. ${ }^{[28]}$ investigated the high-temperature behaviour of $\mathrm{Na}_{2} \mathrm{SiO}_{3}$ by Raman spectroscopy. The authors reported a phase transition at approximately $850 \mathrm{~K}$ and suggested that the transformation is combined with a change in space group symmetry from $C m c 2_{1}$ to $P m c 2_{1}$. A recent high-temperature single crystal diffrac- 


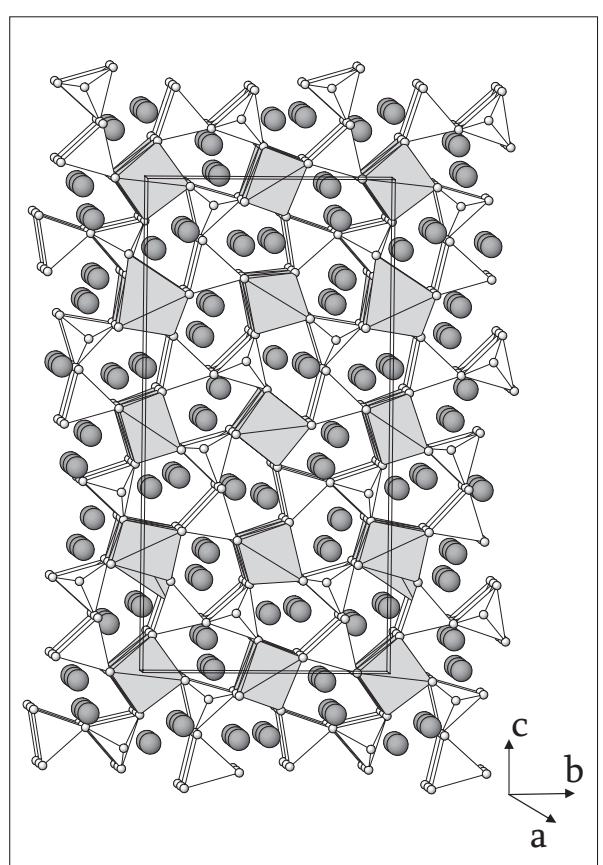

Fig. 3. Side view of the crystal structure of $\mathrm{Na}_{6} \mathrm{Si}_{2} \mathrm{O}_{7}$. $\left[\mathrm{SiO}_{4}\right]$ - and $\left[\mathrm{NaO}_{4}\right]$-tetrahedra are shown in white and grey, respectively. $\mathrm{Na}$ atoms with higher coordination numbers are given as spheres.

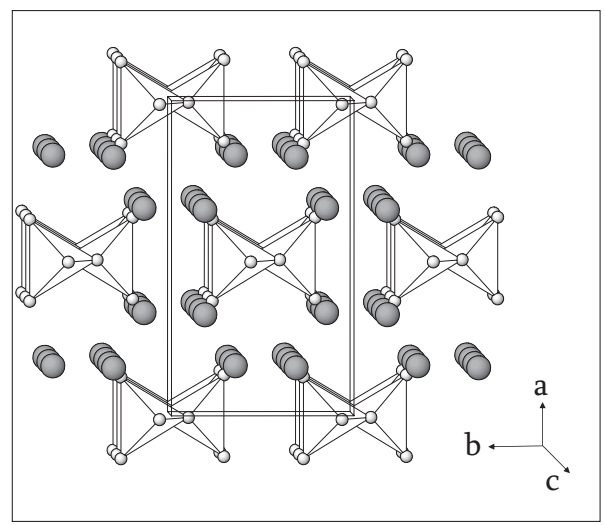

Fig. 4. Side view of the crystal structure of $\mathrm{Na}_{2} \mathrm{SiO}_{3}$.

tion study in our laboratory corroborated the existence of a new phase at elevated temperatures. However, according to our results the symmetry reduction is much more complex and involves both a loss in translational symmetry (tripling of the $b$ lattice constant) as well as a loss in point group symmetry (change from the orthorhombic to the monoclinic crystal system). Therefore, $\mathrm{Na}_{2} \mathrm{SiO}_{3}$ is one of the rare examples where the high-temperature modification has a lower symmetry compared to the phase stable at ambient temperatures.

\section{$\mathrm{Na}_{2} \mathrm{Si}_{2} \mathrm{O}_{5}$}

Sodium disilicates have been extensively studied because of their complex polymorphism. At ambient pressure, as many as four modifications are known to appear as a function of temperature and/

Table 1. Summary of basic crystallographic data of anhydrous sodium silicates

\begin{tabular}{|c|c|c|c|c|c|c|c|c|}
\hline Compound & Space group & $\mathrm{a}[\AA \AA]$ & $\mathrm{b}[\AA \AA]$ & $c[\AA \AA]$ & $\alpha\left[^{\circ}\right]$ & $\beta\left[^{\circ}\right]$ & $\gamma\left[{ }^{\circ}\right]$ & Ref. \\
\hline $\mathrm{Na}_{4} \mathrm{SiO}_{4}$ & $P-1$ & 5.576 & 6.191 & 8.507 & 103.13 & 95.5 & 123.72 & [21] \\
\hline $\mathrm{Na}_{6} \mathrm{Si}_{2} \mathrm{O}_{7}$ & $P-1$ & 5.801 & 11.581 & 23.157 & 89.71 & 88.92 & 89.00 & [25] \\
\hline $\mathrm{Na}_{2} \mathrm{SiO}_{3}$ & $\mathrm{Cmc2}_{1}$ & 10.48 & 6.07 & 4.82 & & & & [27] \\
\hline$\alpha-\mathrm{Na}_{2} \mathrm{Si}_{2} \mathrm{O}_{5}$ & Pnca & 15.422 & 6.409 & 4.896 & & & & [29] \\
\hline$\beta-\mathrm{Na} 2 \mathrm{Si} 2 \mathrm{O} 5$ & $P 112_{1} / b$ & 8.133 & 12.329 & 4.848 & & & 104.2 & [30] \\
\hline$\gamma-\mathrm{Na}_{2} \mathrm{Si}_{2} \mathrm{O}_{5}(\mathrm{RT})$ & C12/c1 & 33.326 & 14.146 & 26.206 & & 108.60 & & [31] \\
\hline$\gamma-\mathrm{Na}_{2} \mathrm{Si}_{2} \mathrm{O}_{5}(\mathrm{HT})$ & $14_{1} / a$ & 11.869 & 11.869 & 7.176 & & & & [31] \\
\hline$\delta-\mathrm{Na}_{2} \mathrm{Si}_{2} \mathrm{O}_{5}$ & $P 12_{1} / n 1$ & 8.393 & 12.083 & 4.843 & & 90.37 & & [32] \\
\hline$\varepsilon-\mathrm{Na}_{2} \mathrm{Si}_{2} \mathrm{O}_{5}$ & $P 2_{1}$ ca & 8.356 & 5.580 & 9.441 & & & & [36] \\
\hline$\kappa-\mathrm{Na}_{2} \mathrm{Si}_{2} \mathrm{O}_{5}$ & Pna2 $_{1}$ & 8.128 & 11.977 & 4.832 & & & & [35] \\
\hline $\mathrm{C}-\mathrm{Na}_{2} \mathrm{Si}_{2} \mathrm{O} 5$ & $P 12_{1} / a 1$ & 8.141 & 23.979 & 4.852 & & 90.15 & & [34] \\
\hline $\mathrm{Na}_{6} \mathrm{Si}_{8} \mathrm{O}_{19}$ & $P 12_{1} / a 1$ & 15.392 & 23.481 & 4.904 & & 90.14 & & [39] \\
\hline $\mathrm{Na}_{2} \mathrm{Si}_{3} \mathrm{O}_{7}-\mathrm{I}$ & $\mathrm{C} 2 / \mathrm{c}(0 \beta 0) \mathrm{s} 0$ & 20.416 & 6.499 & 4.929 & & 90.26 & & [40] \\
\hline $\mathrm{Na}_{2} \mathrm{Si}_{3} \mathrm{O}_{7}-\mathrm{II}$ & $P 12_{1} / c 1$ & 7.192 & 10.604 & 9.805 & & 120.25 & & [41] \\
\hline $\mathrm{Na}_{2} \mathrm{Si}_{3} \mathrm{O}_{7}-\mathrm{HP}$ & C12/c1 & 8.922 & 4.849 & 11.567 & & 102.64 & & [42] \\
\hline $\mathrm{Na}_{2} \mathrm{Si}_{4} \mathrm{O}_{9}-\mathrm{HP}$ & $P 12_{1} / n 1$ & 10.875 & 9.326 & 19.224 & & 90.18 & & [43] \\
\hline $\mathrm{Na}_{8} \mathrm{Si}_{7} \mathrm{O}_{18}-\mathrm{HP}$ & $R-3$ & 7.180 & & & 87.26 & & & [38] \\
\hline
\end{tabular}

Note: Space group settings and unit cell parameters of the compounds have been transformed from the literature data in such a way that - when applicable - the translational period of the zweier single chains (corresponding to the short $4.9 \AA$ lattice parameter) are running parallel to [001]. The labelling of the axes within the figures refers to this table.

or synthesis conditions (phases $\alpha, \beta, \gamma$, $\delta) .{ }^{[29-32]}$ However, $\beta-\mathrm{Na}_{2} \mathrm{Si}_{2} \mathrm{O}_{5}$ has been also found in nature (Kola peninsula, Russia; Mont Saint-Hilaire, Canada). The corresponding mineral is named natrosilite and occurs, for example, in pegmatitc segregations of nepheline syenites. ${ }^{[33]}$ From crystallization experiments of synthetic sodium silicate glasses it has been established that only the $\alpha$ - and the $\beta$ polymorphs have a real thermodynamic stability range. ${ }^{[6]}$ An interconversion of the $\beta$ - to the $\alpha$-phase is observable at about 983 K. Since the $\beta \leftrightarrow \alpha$ transformation is rather sluggish it is possible to preserve the $\alpha$-form at ambient conditions. Upon heating, $\alpha-\mathrm{Na}_{2} \mathrm{Si}_{2} \mathrm{O}_{5}$ undergoes two reversible transitions at $951 \mathrm{~K}$ and 980 K. ${ }^{[6]}$ Therefore, some authors prefer to define three sub-modifications labelled $\alpha_{I}, \alpha_{\text {II }}$ and $\alpha_{\text {III }}$, respectively. Detailed structural studies on the two nonquenchable high-temperature phases $\alpha_{\text {II }}$ and $\alpha_{\text {III }}$ are currently in progress in our laboratory. Preliminary results indicate that the transformations are induced by coupled tiltings of the tetrahedra within the zweier single chains. Metastable single crystals of $\gamma$ - and $\delta-\mathrm{Na}_{2} \mathrm{Si}_{2} \mathrm{O}_{5}$ can be obtained from devitrification at lower temperatures (773-873 K).

Furthermore, the structures of the three quenchable high pressure forms $\mathrm{C}-\mathrm{-}, \mathrm{\kappa}-$, and $\varepsilon-\mathrm{Na}_{2} \mathrm{Si}_{2} \mathrm{O}_{5}$ have been reported. ${ }^{[34-36]}$ The synthesis conditions of these forms are as follows: C: 1023 K/0.1 GPa; к: 973
K/0.3 GPa; $\varepsilon$ : 1373 K/7 GPa. A fourth high pressure phase $\left(\zeta-\mathrm{Na}_{2} \mathrm{Si}_{2} \mathrm{O}_{5}\right)$ described by Kanzaki ${ }^{[37]}$ actually corresponds to a sodium heptasilicate and, consequently, is not a polymorph of sodium disilicate. [38]

As can be seen from Table 1, a common feature of many $\mathrm{Na}_{2} \mathrm{Si}_{2} \mathrm{O}_{5}$ forms is a short lattice constant of about $4.9 \AA$. This value refers to the translation period along the chain direction in $\left[\mathrm{Si}_{2} \mathrm{O}_{6}\right]$ zweier single chains, which represent a common structural feature in most of the modifications. As may be anticipated from the Si:O ratio, the vast majority of sodium disilicates are monophyllosilicates based on $\left[\mathrm{Si}_{2} \mathrm{O}_{5}\right]_{\infty}^{2}$ sheets. Individual layers are composed of six-membered tetrahedral rings. However, the different forms can vary considerably concerning i) the degree of folding of the layers and ii) the sequence of directedness of 'up' and 'down' pointing tetrahedra within the rings (Fig. 5).

On the other hand, $\beta-, \kappa-$ and $\mathrm{C}-\mathrm{Na}_{2} \mathrm{Si}_{2} \mathrm{O}_{5}$ are based on the same type of silicate layer. In these cases, the differences between the structures are due to variations of the ways in which adjacent sheets are stacked, i.e. the three compounds are related by a polytypic relationship (Fig. 6). In $\beta$ - and $\kappa-\mathrm{Na}_{2} \mathrm{Si}_{2} \mathrm{O}_{5}$ an ...ABABA... stacking sequence is realized: Neighbouring layers in the $\beta$-phase are related by inversion centres, whereas the corresponding sheets in the $\kappa$-phase are mapped onto each other by glide planes. The C-phase in turn has an ...ABCD... succession of layers 


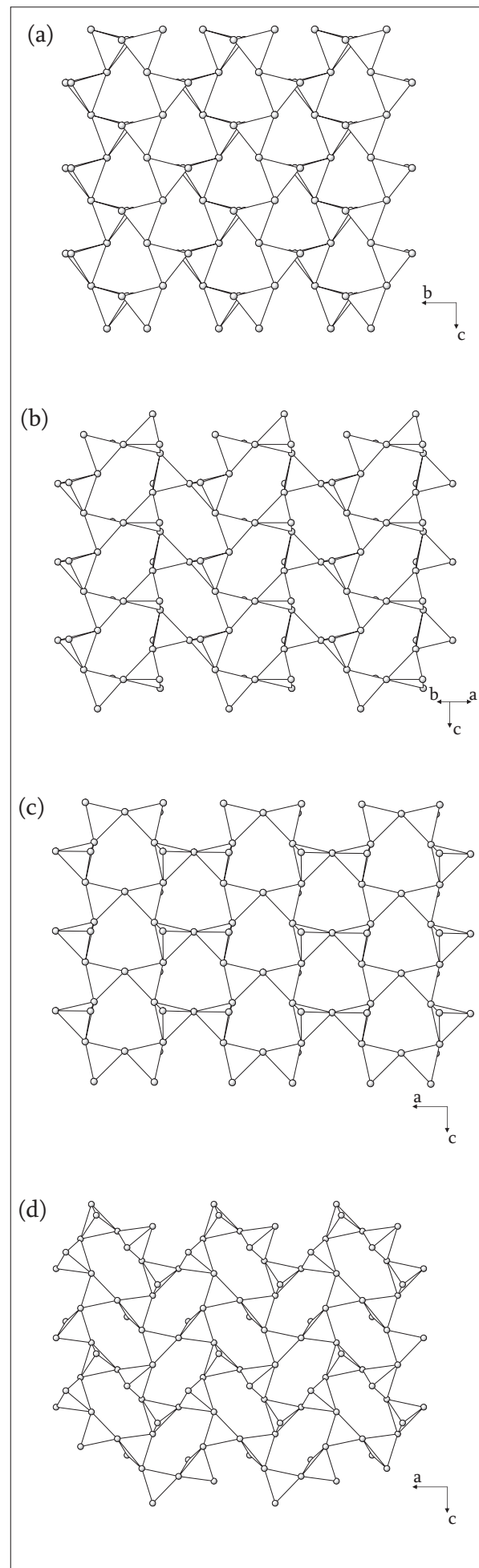

Fig. 5. Single tetrahedral layers in (a) $\alpha$-, (b) $\beta-$, (c) $\delta$-, and (d) $\varepsilon-\mathrm{Na}_{2} \mathrm{Si}_{2} \mathrm{O}_{5}$ in projections perpendicular to the sheets.

and can be considered as being built from a sequence of alternating blocks cut from the $\kappa$ - and the $\beta$-modification, respectively.

A completely distinct topology is realized in the $\gamma$-form of sodium disilicate, one of the metastable modifications. $\gamma-\mathrm{Na}_{2} \mathrm{Si}_{2} \mathrm{O}_{5}$ crystallizes in an extraordinary large monoclinic unit cell $\left(\mathrm{V}=11709 \AA^{3}\right)$ comprising 108 atoms in the asymmetric unit. The compound can be classified as an interrupted tetrahedral framework with

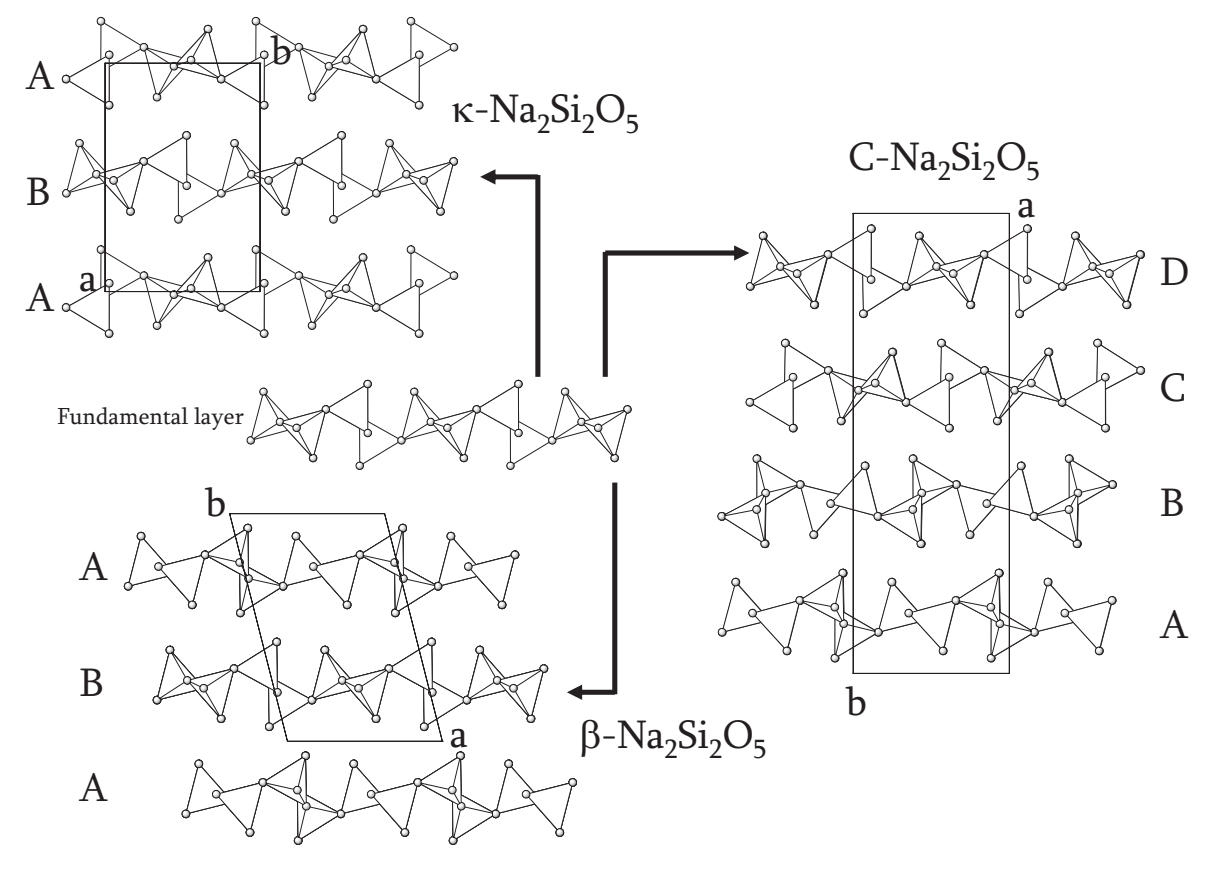

Fig. 6. Polytypic relationship between the structures of $\beta-, \kappa^{-}$and $\mathrm{C}-\mathrm{Na}_{2} \mathrm{Si}_{2} \mathrm{O}_{5}$.
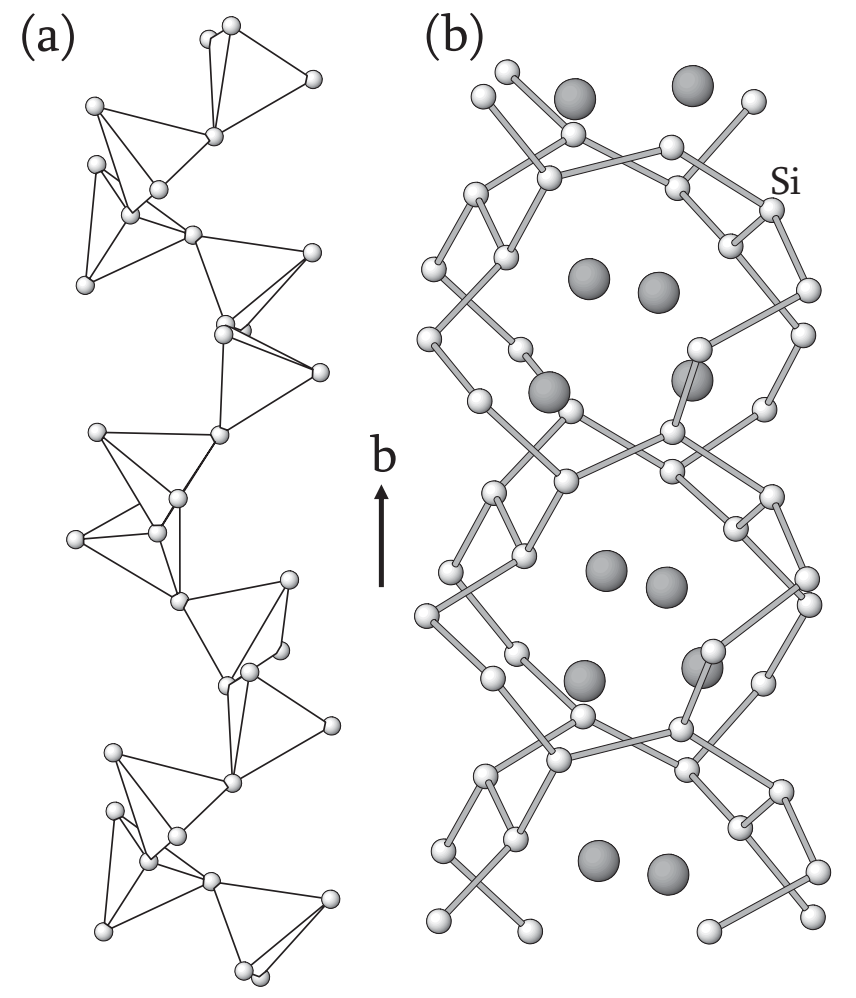

Fig. 7. (a) Side view of a single tetrahedral achter single chain within the framework of $\gamma-\mathrm{Na}_{2} \mathrm{Si}_{2} \mathrm{O}_{5}$. (b) Organization of the silicate framework in $\gamma-\mathrm{Na}_{2} \mathrm{Si}_{2} \mathrm{O}_{5}$ surrounding a single tunnel. Small and big spheres correspond to Si and $\mathrm{Na}$ atoms, respectively. Each of the $\left[8^{2} 10^{2} 10^{2}\right]$ composite building units enclose four $\mathrm{Na}$ atoms.

exclusively $\mathrm{Q}^{3}$-units, i.e. every tetrahedron shares only three of its four corners with neighbouring $\left[\mathrm{SiO}_{4}\right]$-groups. Basic building units of the network are spiral achter single chains. Every four of these chains are linked via common corners, surrounding a central tunnel where the sodium cations are located (Fig. 7). The framework density of the net has a value of $16.4 \mathrm{Si}$ atoms/1000 A. At $836 \mathrm{~K}$ the $\gamma$-phase undergoes a structural phase transition to a tetragonal high-temperature variant with a much smaller unit cell $\left(\mathrm{V}=1011 \AA^{3}\right)$. The transformation is triggered by cooperative rotations of the tetrahedra without any breaking of primary bonds and involves a bisection of the translational period along the spiral chains without changing the general topology of the net. Concerning the relationships between the space group symmetries, the RT-modification of $\gamma-\mathrm{Na}_{2} \mathrm{Si}_{2} \mathrm{O}_{5}$ can be considered as a sub- 
group of index 24 of the HT-phase. Apart from being a crystallochemical curiosity - to our best knowledge three-dimensional three-connected nets for oxides and fluorides containing tetrahedral building units have been observed only for six other inorganic compounds - the structure of $\gamma$ $\mathrm{Na}_{2} \mathrm{Si}_{2} \mathrm{O}_{5}$ is also of interest for the field of glass science. According to Zachariasen's classic random network theory a sodium silicate glass can be considered as a framework of silicate tetrahedra without translational symmetry which is modified by the incorporation of sodium atoms serving to interrupt the network. Actually, the $\gamma$ phase is the only crystalline sodium disilicate where such a tetrahedral network - of course with three-dimensional periodicity - is realized.

\section{$\mathrm{Na}_{6} \mathrm{Si}_{8} \mathrm{O}_{19}$}

The existence of a phase with composition $\mathrm{Na}_{6} \mathrm{Si}_{8} \mathrm{O}_{19}$ has been proven by Williamson and Glasser. ${ }^{[6]}$ However, there is evidence that this compound corresponds to the so-called 'phase W' that had been observed earlier by Yoder and Schairer. ${ }^{[44]}$ $\mathrm{Na}_{6} \mathrm{Si}_{8} \mathrm{O}_{19}$ has a rather limited stability range. ${ }^{[7]}$ It melts incongruently to give sodium disilicate and liquid (at about 1082 $\mathrm{K}$ ) and disproportionates below $973 \mathrm{~K}$ to $\beta-\mathrm{Na}_{2} \mathrm{Si}_{2} \mathrm{O}_{5}$ and $\mathrm{SiO}_{2}$. $\mathrm{Na}_{6} \mathrm{Si}_{8} \mathrm{O}_{19}$ can be attributed to the group of phyllosilicates. ${ }^{[39]}$ Individual sheets can be described as being built by the condensation of zweier single chains. Due to the specific linkage of these chains the layers contain both threefold and fourfold connected tetrahedra in the ratio $\mathrm{Q}^{3}: \mathrm{Q}^{4}=3: 1$ (Fig. 8). A structural linkage to the $\beta$-form of $\mathrm{Na}_{2} \mathrm{Si}_{2} \mathrm{O}_{5}$ is possible. Removing one of the abovementioned zweier single chains results in the formation of $\left[\mathrm{Si}_{6} \mathrm{O}_{15}\right]$-layers which are conformationally similar to those characteristic for $\beta-\mathrm{Na}_{2} \mathrm{Si}_{2} \mathrm{O}_{5}$. In other words, the relatively higher $\mathrm{SiO}_{2}$ content in $\mathrm{Na}_{6} \mathrm{Si}_{8} \mathrm{O}_{19}$ is structurally realized by attaching one additional single chain to this layer: $\left[\mathrm{Si}_{6} \mathrm{O}_{15}\right]+\left[\mathrm{Si}_{2} \mathrm{O}_{4}\right]$ $=\left[\mathrm{Si}_{8} \mathrm{O}_{19}\right]$.

\section{$\mathrm{Na}_{2} \mathrm{Si}_{3} \mathrm{O}_{7}$}

According to the phase equilibria studies listed in the introductory part of this contribution sodium trisilicate $\left(\mathrm{Na}_{2} \mathrm{O} * 3 \mathrm{SiO}_{2}\right)$ has to be considered as a metastable material (at least at ambient pressure). Nevertheless, two different room pressure polymorphs have been reported in the literature, which will be discussed in this section. A third high pressure modification will be addressed in a later paragraph.

The first form of $\mathrm{Na}_{2} \mathrm{Si}_{3} \mathrm{O}_{7}$ was already prepared in $1966^{[6]}$ by annealing a stoichiometric glass at $923 \mathrm{~K}$. A provisional structural investigation ${ }^{[45]}$ attributed this phase to the orthorhombic crystal system. Furthermore, the author reported a single

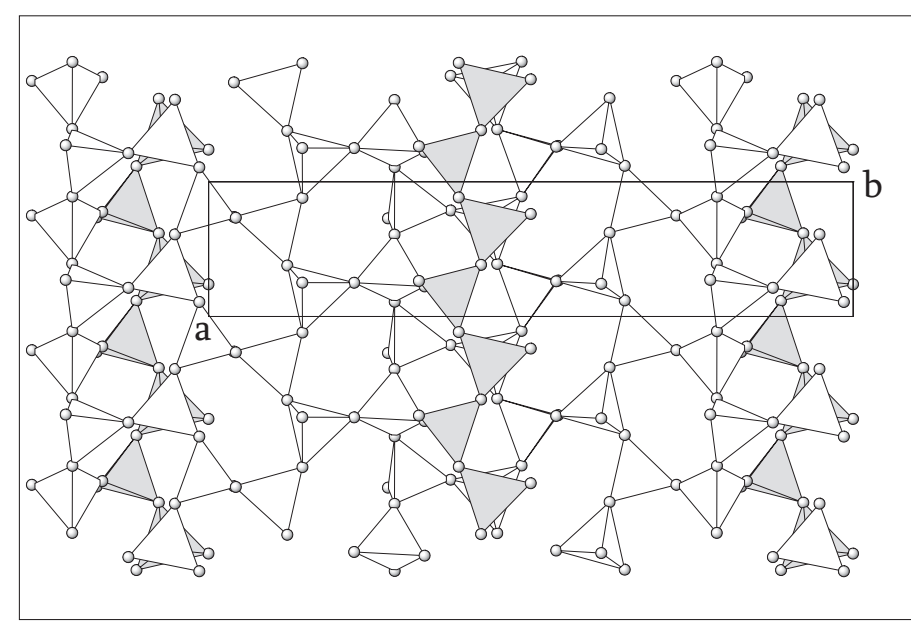

Fig. 8. The tetrahedral arrangement within a single layer of $\mathrm{Na}_{6} \mathrm{Si}_{8} \mathrm{O}_{19}$ shown in a projection perpendicular to the layers. Three- and fourfold connected tetrahedra can be identified. In comparison with the $\beta$-phase of $\mathrm{Na}_{2} \mathrm{Si}_{2} \mathrm{O}_{5}$ one 'additional' zweier single chain (marked in grey) has been attached.

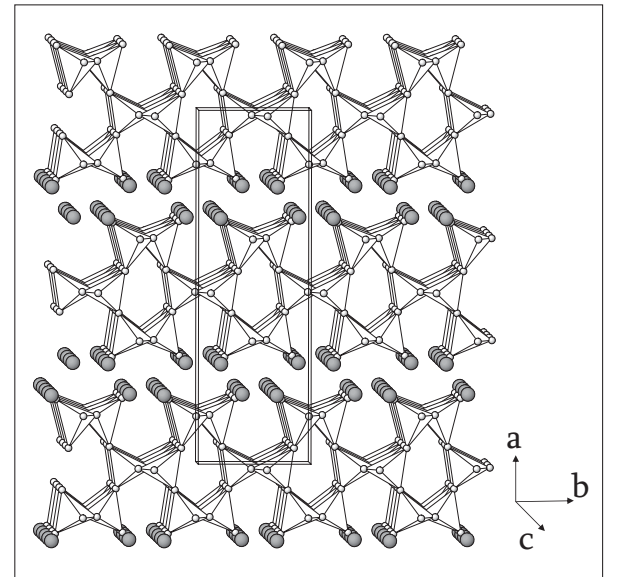

Fig. 9. Side view of the average crystal structure of $\mathrm{Na}_{2} \mathrm{Si}_{3} \mathrm{O}_{7}-$ I. For sake of clarity, only one orientation of the disordered central chain has been drawn.

crystal diffraction pattern showing the presence of additional satellite reflections with non-integral indices. A structure solution of the average structure based on the main reflections indicated the existence of $\left[\mathrm{Si}_{3} \mathrm{O}_{7}\right]$ layers. A recent re-investigation of form I i) showed that the compound is actually monoclinic with a pseudo-orthorhombic cell (and is therefore affected by twinning) and ii) confirmed the incommensurately modulated nature of the material.[40] The structure was successfully described in $(3+1)$-dimensional superspace (superspace group $C 2 / c(0 \beta 0) \mathrm{s} 0$, modulation wavevector $\left.\mathbf{q}=0.562 \mathbf{b}^{*}\right)$. As can be seen from Fig. 9, the silicate tetrahedra of the 'central' chain is $\mathrm{Q}^{4}$-connected, while the 'outer' chain has a lower connectivity of three. Actually, the modulation affects primarily the central chain. In the average structure, the central chain is disordered. The resulting two orientations are enantiomorphous and can be arbitrarily called left(L)- and right( $\mathrm{R})$-oriented. Crenel-type modulation functions were used to account for the aperiodic sequence of these rightand left-handed chains in the real struc- ture along [010]. After seven or eight R-L alternations R-R or L-L pairs of equally oriented chains follow. A fragment of such a sequence could be: ...R-L-R-L-R-R-L-RL-R-L-R-L-L-R-L-R-L-R-L-R-R-L...

As already discussed in ref. [45], the crystal structures of $\mathrm{Na}_{2} \mathrm{SiO}_{3}, \alpha-\mathrm{Na}_{2} \mathrm{Si}_{2} \mathrm{O}_{5}$ and $\mathrm{Na}_{2} \mathrm{Si}_{3} \mathrm{O}_{7}$ are closely related. By an increasing condensation of additional zweier single chains via common corners the anion complexes of the latter two compounds can be derived from the structure of sodium metasilicate (Fig. 10).

A second $\mathrm{Na}_{2} \mathrm{Si}_{3} \mathrm{O}_{7}$ polymorph was synthesized from $\mathrm{Na}_{2} \mathrm{Si}_{3} \mathrm{O}_{7} \mathrm{xH}_{2} \mathrm{O}$ (space group $P 2 / c, a=7.3087 \AA, b=12.7246$ $\AA, c=9.0913 \AA, \beta=119.01^{\circ}$ ) by a careful thermally induced dehydration at 713 K. ${ }^{[46]}$ An ab initio structure determination of the dehydration product from conventional powder diffraction data coupled with a subsequent Rietveld analysis revealed that the material belongs to the group of interrupted framework silicates

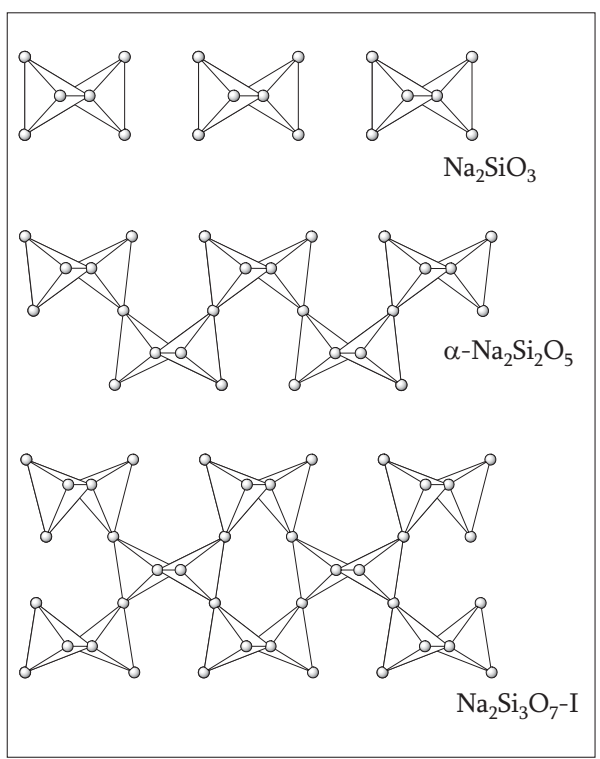

Fig. 10. Comparison of the crystal structures of $\mathrm{Na}_{2} \mathrm{SiO}_{3}, \alpha-\mathrm{Na}_{2} \mathrm{Si}_{2} \mathrm{O}_{5}$ and $\mathrm{Na}_{2} \mathrm{Si}_{3} \mathrm{O}_{7}-\mathrm{I}$ (average structure). 


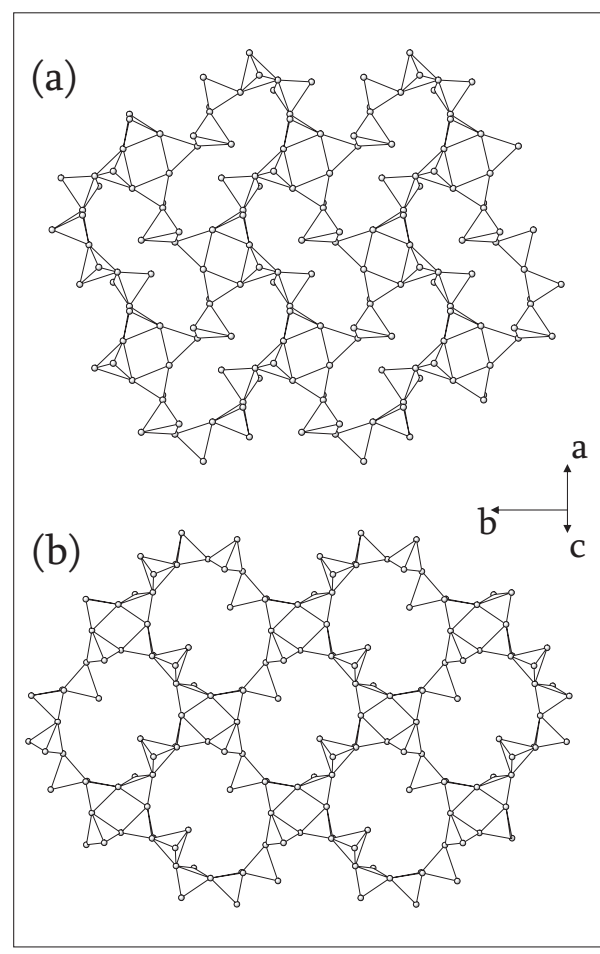

Fig. 11. Single tetrahedral layers parallel (10-2) containing four- and twelve membered rings in (a) $\mathrm{Na}_{2} \mathrm{Si}_{3} \mathrm{O}_{7}-\mathrm{Il}$ and (b) $\mathrm{Na}_{2} \mathrm{Si}_{3} \mathrm{O}_{7} \mathrm{xH}_{2} \mathrm{O}$.

of four- and three-connected $\left[\mathrm{SiO}_{4}\right]-$ tetrahedra $\left(\mathrm{Q}^{3}: \mathrm{Q}^{4}\right.$-ratio $\left.=2: 1\right) \cdot{ }^{[41]}$ Within the network the sodium cations are coordinated by four to six oxygen ligands. The porous character of the new phase is reflected in a framework density FD $=18.6 \mathrm{~T}$-atoms $/ 1000 \AA^{3}$, a value that is comparable to those observed in zeolitic materials. Actually, the framework topology is identical to the one that is observed in the corresponding monohydrate. Differences can be primarily attributed to tetrahedral rotations. A concise description of the tetrahedral substructure can be obtained considering $6 \AA$ wide slabs cut from the framework parallel to (10-2) (Fig. 11a). The slab contains a layer of tetrahedra arranged in four- and twelvemembered rings. With regard to this slab, the sodium atoms too are approximately located in layers parallel to (10-2), close to the apical oxygens. Removing the water molecules from the hydrated phase without structural changes would result in energetically unfavourable almost quadratic planar coordination environments for some of the Na atoms. Therefore, the structure relaxes and a more stable distorted tetrahedral arrangement is achieved (Fig. 11a and 11b).

\section{Mixed Tetra- and Hexaoxosilicates}

The phase relations in the $\mathrm{Na}_{2} \mathrm{O}-\mathrm{SiO}_{2}$ system at elevated pressures and temperatures have been studied by several authors

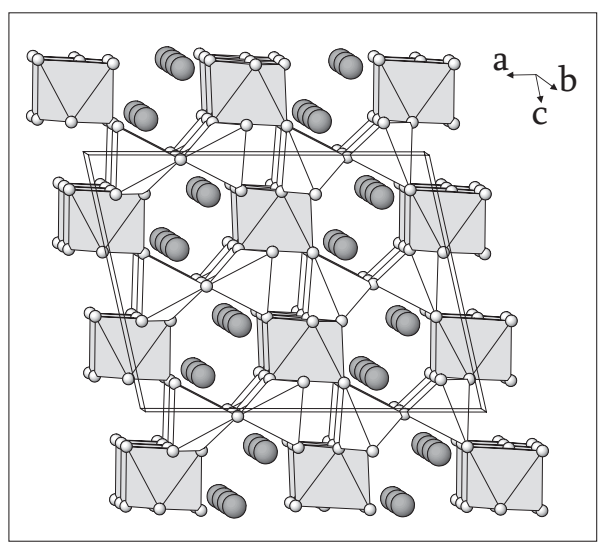

Fig. 12. Side view of the crystal structure of $\mathrm{Na}_{2} \mathrm{Si}_{3} \mathrm{O}_{7}-\mathrm{HP}$.

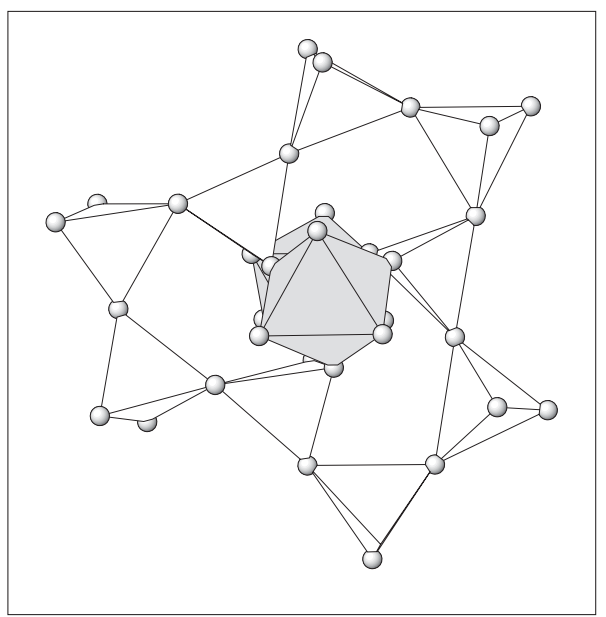

Fig. 13. Fragment of the tetrahedral-octahedral framework in $\mathrm{Na}_{2} \mathrm{Si}_{4} \mathrm{O}_{9}-\mathrm{HP}$. Constricted tetrahedral $\left[\mathrm{Si}_{9} \mathrm{O}_{27}\right]$-rings are centred around two $\left[\mathrm{SiO}_{6}\right]$-octahedra residing above and below the mean plane of the ring.

using ex situ and in situ experimental techniques (powder X-ray diffraction, ${ }^{29} \mathrm{Si}$ MAS NMR spectroscopy, vibrational spectroscopy).[36-38,42,43,47-51] Tetrahedrally based high-pressure polymorphs of sodium disilicate $(\mathrm{C}, \kappa, \varepsilon)$ have been already mentioned above. The focus of this paragraph will be on compounds that have been prepared at pressures high enough to induce a partial transition in the coordination number of silicon from four- to sixfold. However, it should be emphasized that all known structural investigations on high-pressure sodium silicates have been performed on samples that were quenched to ambient conditions.

\section{$\mathrm{Na}_{2} \mathrm{Si}_{3} \mathrm{O}_{7}-\mathrm{HP}$}

At the bulk composition $\mathrm{Na}_{2} \mathrm{O} * 3 \mathrm{SiO}_{2}$ a novel high-pressure polymorph was obtained at $9 \mathrm{GPa} / 1473 \mathrm{~K}$. Within the monoclinic compound both tetrahedrally and octahedrally coordinated silicon can be found. The ${ }^{[6]} \mathrm{Si}:{ }^{[4]} \mathrm{Si}$ ratio has a value of $1: 2$. The structure is based on $\left[\mathrm{Si}_{2} \mathrm{O}_{7}\right]$-di- mers which are linked to $\left[\mathrm{SiO}_{6}\right]$-octahedra by sharing common corners, i.e. the structural formula can be written as $\mathrm{NaSi}\left[\mathrm{Si}_{2} \mathrm{O}_{7}\right]$ (Fig. 12). The resulting mixed tetrahedraloctahedral framework incorporates the sodium atoms which are irregularly coordinated by six oxygen anions. Within the network four- and six-membered rings of $\left[\mathrm{SiO}_{\mathrm{n}}\right]$-polyhedra can be identified.

\section{$\mathrm{Na}_{2} \mathrm{Si}_{4} \mathrm{O}_{9}-\mathrm{HP}$}

Single crystals of sodium tetrasilicate were grown in the presence of melt in the pressure/temperature regime from $6 \mathrm{GPa} / 1273 \mathrm{~K}$ to $9 \mathrm{GPa} / 1773 \mathrm{~K}$. The structure also contains four- and six-fold coordinated $\mathrm{Si}$, but in the ratio ${ }^{[6]} \mathrm{Si}:{ }^{: 4]} \mathrm{Si}=$ 1:3. Each nine of the $\mathrm{SiO}_{4}$-tetrahedra are linked to strongly constricted rings (Fig. 13) which are arranged in layers parallel to (010). The rings are centred around two single $\mathrm{SiO}_{6}$-octahedra residing above and below the rings, respectively. Both octahedra provide linkage to the adjacent layers. Therefore, the formula of high pressure sodium tetrasilicate can restated as $\mathrm{Na}_{6} \mathrm{Si}_{3}\left[\mathrm{Si}_{9} \mathrm{O}_{27}\right]$.

\section{$\mathrm{Na}_{8} \mathrm{Si}_{7} \mathrm{O}_{18}-\mathrm{HP}$}

The crystal structure of $\mathrm{Na}_{8} \mathrm{Si}_{7} \mathrm{O}_{18}$ has been determined from a sample prepared at $9 \mathrm{GPa} / 1273 \mathrm{~K} .{ }^{[38]}$ The trigonal compound (space group R-3) can be considered as a three-dimensional network consisting of $\left[\mathrm{Si}_{6} \mathrm{O}_{18}\right]$-rings which are interlinked with $\left[\mathrm{SiO}_{6}\right]$-octahedra (Fig. 14). The sodium atoms have eight nearest oxygen neighbours. Fleet ${ }^{[38]}$ suggested that $\mathrm{Na}_{8} \mathrm{Si}_{7} \mathrm{O}_{18}$ (or $\mathrm{Na}_{8} \mathrm{Si}\left[\mathrm{Si}_{6} \mathrm{O}_{18}\right]$ ) undergoes a displacive structural phase transition upon decompression which involves orderdisorder processes among the sodium cations. The space group of the modification stable at the synthesis conditions

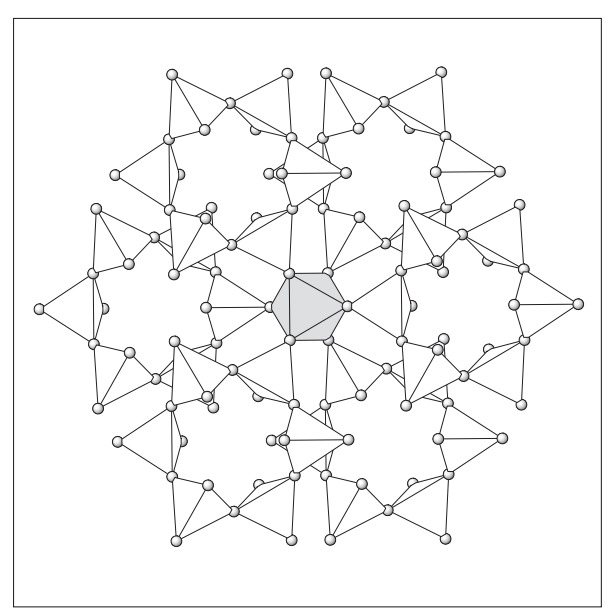

Fig. 14. Projection of a fragment of the tetrahedral-octahedral framework in $\mathrm{Na}_{8} \mathrm{Si}_{7} \mathrm{O}_{18}-$ $\mathrm{HP}$ parallel to [111]. A single [ $\left.\mathrm{SiO}_{6}\right]$ - octahedron connects a total of six different puckered $\left[\mathrm{Si}_{6} \mathrm{O}_{18}\right]$-rings. 
was proposed to be $R-3 m$. However, no in situ diffraction study has been performed to verify this hypothesis. The same author pointed out that the three different high-pressure silicates discussed in the previous sections can be attributed to a homologous series $\mathrm{Na}_{2 \mathrm{k}} \mathrm{Na}_{2(\mathrm{~m}-\mathrm{k})} \mathrm{Si}_{\mathrm{m}-\mathrm{k}}\left[\mathrm{Si}_{\mathrm{n}-}\right.$ $\left.{ }_{\mathrm{m}+\mathrm{k}} \mathrm{O}_{2 \mathrm{n}+\mathrm{m}}\right]$, with $\mathrm{k}<\mathrm{m}<\mathrm{n}$ and $(\mathrm{n}-\mathrm{m}+\mathrm{k})$ $\geq 3 / 2$ (m-k). Na $2 \mathrm{Si}^{\mathrm{m}}\left[\mathrm{Si}_{2} \mathrm{O}_{7}\right], \mathrm{Na}_{6} \mathrm{Si}_{3}\left[\mathrm{Si}_{9} \mathrm{O}_{27}\right]$ and $\mathrm{Na}_{8} \mathrm{Si}\left[\mathrm{Si}_{6} \mathrm{O}_{18}\right]$ can be regarded as members of the series with $\mathrm{k}=0, \mathrm{~m}=1$, $\mathrm{n}=3 ; \mathrm{k}=0, \mathrm{~m}=3, \mathrm{n}=12$ and $\mathrm{k}=3, \mathrm{~m}=$ $4, \mathrm{n}=7$, respectively.

\section{Structurally Undetermined Sodium Silicates}

In addition to the sodium silicates that have been presented in the previous sections there are still several compounds which lack a detailed structural characterization. These structurally unknown materials are located in the vicinity of compositional boundaries of the binary system. For example, two different ambient pressure variations of $\mathrm{Na}_{2} \mathrm{Si}_{4} \mathrm{O}_{9}$ have been mentioned in the literature. One of these modifications is ertixiite, a mineral approved by the Commission on New Minerals, Nomenclature and Classification of the International Mineralogical Association. So far, ertixiite has been described only once. It was found as linings of miarolitic cavities in a Ta-Nb-Be-bearing granite pegmatite (Altay mine, China). Rubo et al. ${ }^{[52]}$ attributed the mineral to the cubic crystal systems and reported a lattice constant of $a=5.975 \AA$.

On the other hand, two independent investigations ${ }^{[17,18]}$ confirmed the existence of a metastable $\mathrm{Na}_{2} \mathrm{Si}_{4} \mathrm{O}_{9}$-phase that can be obtained from the crystallisation of the corresponding glass at temperatures of about $993 \mathrm{~K}$. The reported powder diffraction patterns are in good agreement. In this context it noteworthy that the entry no. 00-038-0020 of the Powder Diffraction File that is based on the data of Neilson et al. ${ }^{[17]}$ lists incorrect unit cell parameters for $\mathrm{Na}_{2} \mathrm{Si}_{4} \mathrm{O}_{9}$. The given cell actually refers to the lattice constants of the compound $\mathrm{Na}_{6} \mathrm{Si}_{8} \mathrm{O}_{19}$ that has been also studied in the same publication.

The very $\mathrm{Na}_{2} \mathrm{O}$-rich side of the phase diagram has been the subject of a recent study based on differential thermal analysis. ${ }^{[10,11]}$ From the shape of the liquidus curve the existence of a previously unknown compound was inferred whose composition is probably $\mathrm{Na}_{10} \mathrm{SiO}_{7}$. Upon cooling the new phase seems to decompose slowly at $1064 \mathrm{~K}$ into $\mathrm{Na}_{2} \mathrm{O}$ and $\mathrm{Na}_{4} \mathrm{SiO}_{4}$. Further evidence for the existence of this new material came from X-ray powder diffraction, although the recorded diffraction patterns always indicated the simultaneous presence of larger amounts of other phases such as $\mathrm{Na}_{2} \mathrm{O}, \mathrm{Na}(\mathrm{OH})$ and $\mathrm{Na}_{4} \mathrm{SiO}_{4}$.

\section{Concluding Remarks}

During the last years considerable progress has been made concerning the reconnaissance of the crystal chemistry of sodium silicates. This success is undoubtedly related to important improvements of the instrumental as well as theoretical tools of crystallography. The introduction of modern area detectors such as chargecoupled devices or image plates, for example, has revolutionized experimental studies of crystal structures. Compared to the era when point detectors were state of the art, the higher sensitivity of the new generation of detectors allows investigations of much smaller single crystalline samples or to perform in situ temperature or pressure dependent studies in short times. Furthermore, the possibility to collect two-dimensional diffraction images greatly facilitates the recognition and handling of incommensurately modulated structures or complex twinning effects. Complimentary to the developments in the field of single crystal diffraction, $a b$ initio structure determination even from laboratory powder diffraction data has become a mature technique and is frequently employed when only polycrystalline material is available. In retrospect to the topics and problems that have been addressed in this article it becomes immediately clear why the structural elucidation of some of the sodium silicates had to wait for several decades.

\section{Acknowledgements}

The author is indebted to Dr. Srdjan Rakić, Dr. Hannes Krüger, Mag. Erik Arroyabe and other active or former members of the applied mineralogy / crystallography groups at the Universities of Innsbruck and Bremen, respectively, for their scientific input and their devotion to the field of sodium silicates.

Received: June 8, 2010

[1] G. W. Morey, J. Am. Chem. Soc. 1913, 35, 1693

[2] G. W. Morey, L. Bowen, J. Phys. Chem. 1924, 28,1167

[3] F. C. Kracek, J. Phys. Chem. 1930, 34, 1583.

[4] J. D'Ans, J. Löffler, Z. Anorg. Allg. Chem. 1930 191,1

[5] A. Willgallis, K. J. Range, Glastechn. Ber. 1963, 37, 194

[6] J. Williamson, F. P. Glasser, Phys. Chem. Glasses 1966, 7, 127.

[7] K. A. Shahid, F. P. Glasser, Phys. Chem. Glasses 1971, 12, 50 .

[8] A. I. Zaitsev, N. E. Shelkova, N. P. Lyakishev, B. M. Mogutnov, Phys. Chem. Chem. Phys. 1999, 1, 1899 .

[9] A. Meshalkin, A. Kaplun, Russ. J. Inorg. Chem. 2003, 48, 1567

[10] M. Ryś, PhD-Thesis RWTH Aachen, 2007.
[11] M. Ryś, M. Müller, Thermochim. Acta 2010 , 502,8 .

[12] W. E. Halter, B. O. Mysen, Chem. Geol. 2004, $213,115$.

[13] H. P. Rieck, Nachr. Chem. Tech. Lab. 1996, 44, 699.

[14] F. Wolf, W. Schwieger, Z. Anorg. Allg. Chem 1979, 457, 224

[15] I. Heinemann, G. H. Frischat, J. Am. Ceram. Soc. 1990, 73, 3712.

[16] G. Scherer, D. Uhlmann, J. Cryst. Growth 1975, $29,12$.

[17] G. Neilson, J. Weinberg, J. Non-Cryst. Solids 1984, 63, 365 .

[18] G. Mogensen, N. H. Christensen, Phys. Chem. Glasses 1981, 22, 17.

[19] M. Kanzaki, X. Xue, J.F. Stebbins, Phys. Earth Planet Int. 1998, 107, 9.

[20] H. Maekawa, T. Yokokawa, Geochim. Cosmochim. Acta 1997, 61, 2569.

[21] M. G. Barker, P. G. Gadd, J. Chem. Res. 1981, 9, 274

[22] W. H. Baur, E. Halwax, H. Völlenkle, $M h$. Chem. 1986, 117, 793.

[23] J. Löffler, Glastechn. Ber. 1969, 42, 92.

[24] K. Kautz, G. Müller, W. Schneider, Glastechn. Ber. 1970, 43, 377.

[25] V. Kahlenberg, T. Langreiter, E. Arroyabe, Z. Anorg. Allg. Chem., 2010, 636, 1974.

[26] A. Grund, M. Pizy, Acta Cryst. 1952, 5, 837.

[27] W. S. McDonald, D. W. J. Cruickshank, Acta Cryst. 1967, 22, 37.

[28] P. Richet, B. O. Mysen, D. Andrault, Phys. Chem. Mineral. 1996, 23, 157.

[29] A. K. Pant, D. W. J. Cruickshank, Acta Cryst. 1968, B24, 13.

[30] A. K. Pant, Acta Cryst. 1968, B24, 1077.

[31] V. Kahlenberg, S. Rakić, C. Weidenthaler, Z. Kristallogr. 2003, 218, 421.

[32] V. Kahlenberg, G. Dörsam, M. WendschuhJosties, R.X. Fischer, J. Solid State Chem. 1999, 146, 380.

[33] M. Fleischer, G. Y. Chao, J. A. Mandarino, Am. Mineral. 1976, 61, 338.

[34] S. Rakić, V. Kahlenberg, C. Weidenthaler, B. Zibrowius, Phys. Chem. Mineral. 2002, 29, 477.

[35] S. Rakić, V. Kahlenberg, B. C. Schmidt, Solid State Sci. 2003, 5, 473.

[36] M. E. Fleet, G. S. Henderson, J. Solid State Chem. 1995, 119, 400.

[37] M. Kanzaki, X. Xue, J. F. Stebbins, EOS Trans. Am. Geophys. Union 1989, 70, 1418.

[38] M. E. Fleet, Am. Mineral. 1998, 83, 618

[39] H. Krüger, V. Kahlenberg, R. Kaindl, Solid State Sci. 2005, 7, 1390.

[40] H. Krüger, V. Kahlenberg, K. Friese, Acta Cryst. 2006, B62, 440

[41] V. Kahlenberg, B. Marler, J. C. Muñoz Acevedo, J. Patarin, Solid State Sci. 2002, 10, 1285.

[42] M. E. Fleet, G. S. Henderson, Phys. Chem. Mineral. 1995, 22, 383

[43] M. E. Fleet, Am. Mineral. 1996, 81, 1105.

[44] H. S. Yoder, J. F. Schairer, Ann. Rep. Geophys. Lab. 1963-1964, 79.

[45] P. B. Jamieson, Nature 1967, 214, 794.

[46] A. Matijasic, B. Marler, J. Patarin, Int. J. Inorg. Mater. 2000, 2, 209.

[47] X. Xue, J. F. Stebbins, M. Kanzaki, P. F. McMillan, B. Poe, Am. Mineral 1991, 76, 8.

[48] X. Xue, J. F. Stebbins, Phys. Chem. Mineral. 1993, 20, 297.

[49] X. Xue, J. F. Stebbins, M. Kanzaki, Am. Mineral. 1994, 79, 31.

[50] M. E. Fleet, G. S. Henderson, Phys. Chem. Mineral. 1997, 24, 345

[51] M. Kanzaki, X. Xue, J. F. Stebbins, Phys. Earth Plan. Inter. 1998, 107, 9.

[52] Z. Rubo, H. Fengming, D. Chongliang, Geochemistry (China) 1985, 4, 192. 